\title{
THE BLOOD CHOLESTEROL CONTENT IN CHILDHOOD
}

\author{
BY \\ VIDA J. M. STARK, M.D.* \\ (From the Department of Paediatrics, Glasgow University, and the Biochemical \\ Laboratory, Royal Hospital for Sick Children, Glasgow) \\ Although a knowledge of variations in the cholesterol content of the blood \\ has not been shown to be of direct value in clinical medicine, the fact that this \\ substance forms the basis of many of the essential hormones and vitamins gives \\ it an important place in the chemistry of living processes. It has been shown \\ that cholesterol, bile acids, vitamin D and the male and female hormones have \\ a common carbon skeleton (Gainsborough, 1935). Ruzicka and his colleagues \\ (quoted by Callow and Parkes, 1937) have prepared androsterone from it, \\ and Vollmer and others (1927) have shown that vitamin D can be formed from \\ it by irradiation. From such work it is apparent that cholesterol must rank as \\ one of the important constituents of the living body.
}

\section{The blood cholesterol content in health}

The blood cholesterol content has been extensively studied both in healthy adults and children, but the results have shown a wide range of variation. In table 1 the figures recorded by different workers for healthy adults are shown. These figures range from $100 \mathrm{mgm}$. per cent. to $392 \mathrm{mgm}$. per cent. In healthy

TABLE 1

THE BLOOD CHOLESTEROL CONTENT IN NORMAL ADULTS

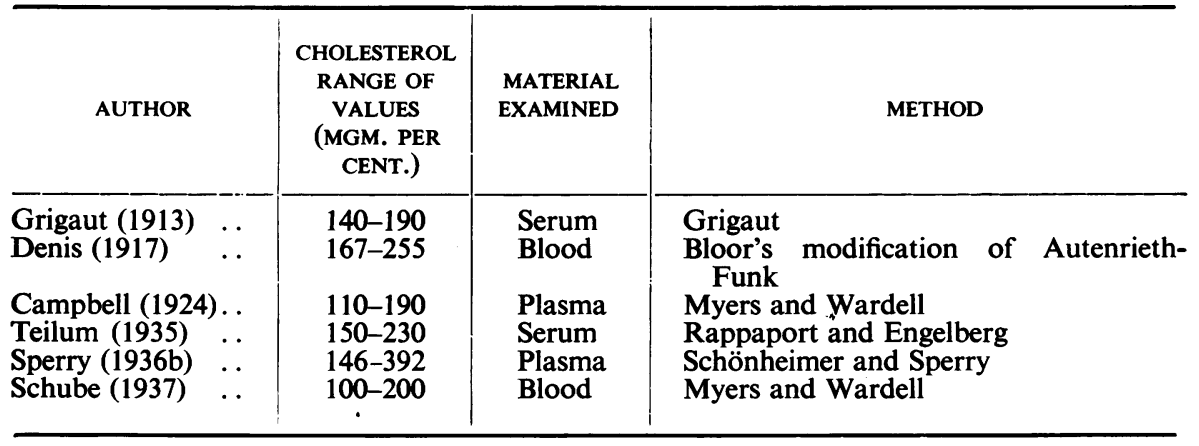

* Part of this work was performed during the tenure of a Muirhead Research Scholarship. 
TABLE 2

THE BLOOD CHOLESTEROL CONTENT IN NORMAL CHILDREN

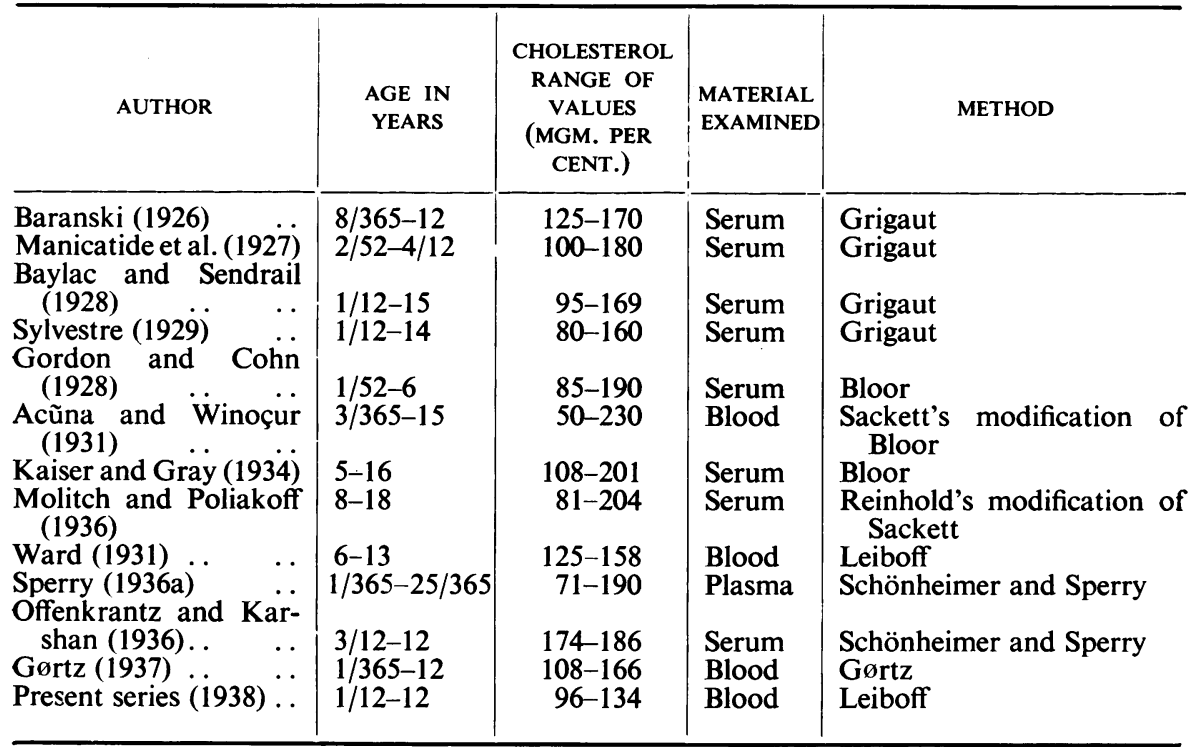

children a similar, though rather less wide, range of variations is shown (table 2). It is difficult to account for these discordant results. They cannot be explained by the use of different methods of estimation, for even one worker using the same technique in all experiments may get gross variations from case to case. Neither can these variations be attributed to difference in diet. This question has been studied by many workers (Chaikoff, McGavack and Kaplan, 1934; Blottner and Fitz, 1934; Blottner, 1935; Wilson and Hanner, 1934; and Bloor, 1916 and 1933). Although there is still some lack of agreement, a large number of those who have studied the subject believe that cholesterol variations are quite independent of food intake. Furthermore, the cholesterol content does not appear to vary with age. In the present series, in which the ages ranged from a few months to twelve years, no significant variations in the blood cholesterol content could be detected (chart I).

In view of this, and before attempting to study changes in blood cholesterol content occurring in disease, it was thought essential to determine the normal range of variation in healthy children, excluding as far as possible extraneous influences. Owing to the undesirability of withdrawing more than a small quantity of blood from young children, a modification of the micro-method of Leiboff (1924) was employed, which entails the withdrawal of only $0 \cdot 2$ c.c. of blood. The estimations were carried out on oxalated whole blood and were made after a four or five hours' fast. Sixty-two apparently healthy children who had not suffered from any recent illness were studied. The majority were admitted to hospital on account of some surgical condition, such as congenital dislocation of the hip, talipes or hernia, and a few were out-patients attending 
the dental clinic; cases of alveolar abscess were excluded. All the estimations were made prior to any surgical procedure. The results do not show such a wide range as those recorded by some other workers. The highest figure obtained was $134 \mathrm{mgm}$. per cent. and the lowest $96.0 \mathrm{mgm}$. per cent. (chart I) The average figures for various ages show only minor differences. No significant difference could be found between the sexes; the average for males was $114.1 \mathrm{mgm}$. per cent. and for females $110.9 \mathrm{mgm}$. per cent. It has been claimed

\section{CHART I}

\section{The Blood Cholesterol in Normal Children}

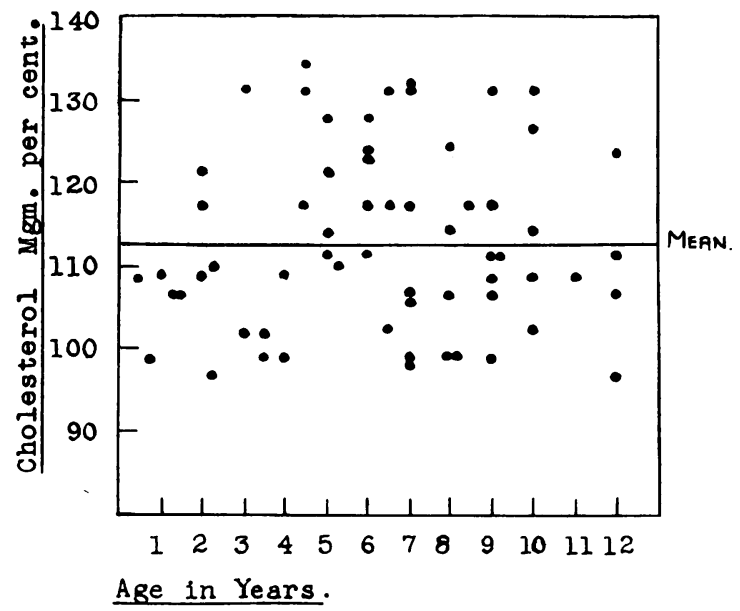

that there is a seasonal variation in the blood cholesterol content (Currie, 1924; Kaiser and Gray, 1934), but the present results do not show this. The average figure for the winter months was $110.7 \mathrm{mgm}$. per cent. and for summer months $114.8 \mathrm{mgm}$. per cent. It would appear, therefore, that using the technique described above, the normal values for children up to the age of twelve years lie between $96.0 \mathrm{mgm}$. per cent. and $134 \mathrm{mgm}$. per cent., and that these figures are not materially influenced by diet, age, sex or season.

\section{The blood cholesterol in disease in childhood}

Most authorities agree that there is diminution in the blood cholesterol content in acute infections, in parenchymatous liver diseases and in hyperthyroidism, whereas in nephrosis, obstructive jaundice and in hypothyroidism it is increased. In the present paper a study of the blood cholesterol content in pneumonia and empyema, acute rheumatism and acute nephritis has been made. These diseases represent types of acute infections. In addition, series of cases of nephrosis and obstructive and haemolytic jaundice have been investigated. 
Pneumonia and empyema. There is fairly general agreement that in pneumonia there is diminution of the blood cholesterol content during the acute stage of the disease (Kipp, 1920; Chauffard et al., 1920; Steiner and Turner, 1940), and Chauffard and Steiner with their co-workers claim that there is hypercholesterolaemia during convalescence. Similar results have been found by most of those who have studied the question in children (Lesné et al., 1929; Stroesser, 1936). On the other hand, Simonini (1933) and Goldbloom and Gottlieb (1927) have failed to confirm these results.

The present series comprises sixty-two children suffering from acute lobar or broncho-pneumonia. Thirty-four of these were under two years of age. In many of the patients the cholesterol was estimated two, three and four times a week during the course of the illness and convalescence. Though in the great majority of the cases the cholesterol values lay within normal limits, higher values tended to occur during convalescence than during the acute stage of the disease (charts II and III). This was specially noticeable in children under two years of age. Children under two years of age who were suffering from a second or third attack gave low results and in them there was not the same

ChART II

The BLOOD ChOLEsterol in PNeUmonia CHILDREN OVER Two YeARS

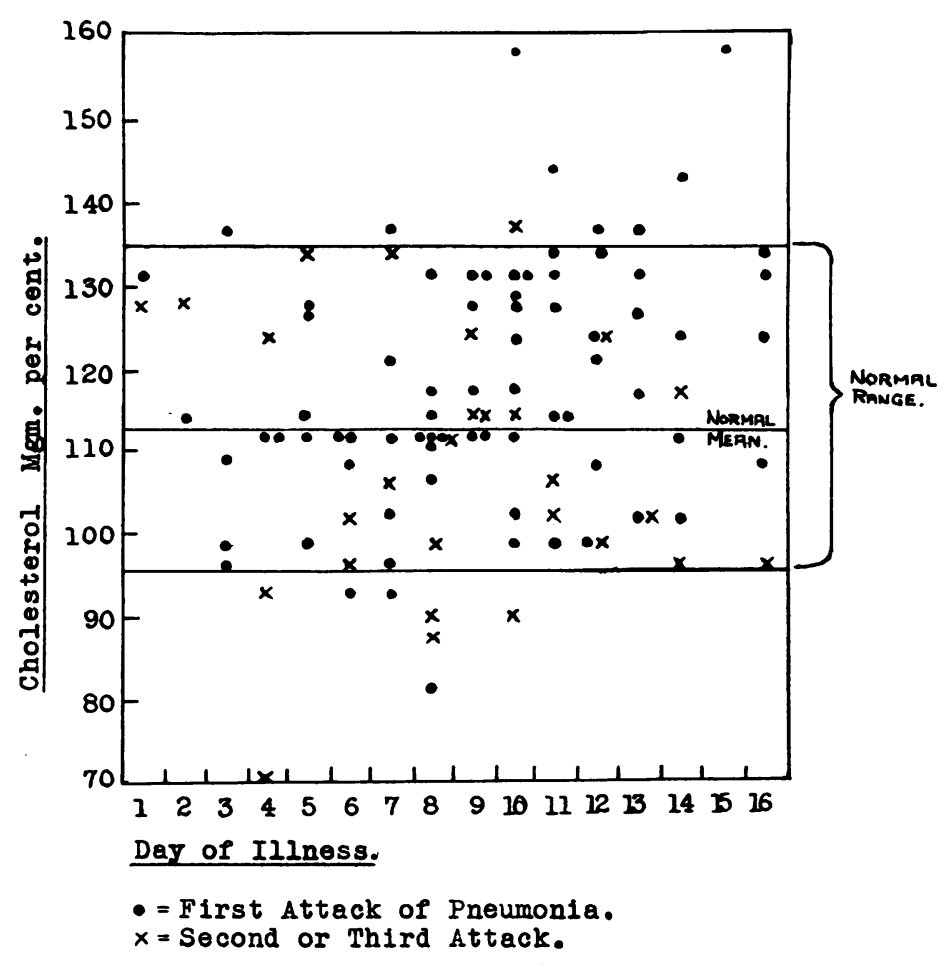


tendency for the values to rise with convalescence. It is difficult to assess the significance of this, though it is possible that recurrent infection may cause a lowering of blood cholesterol in the same way that, as shown by Grigaut (1913), it is lowered in prolonged acute infections. No correlation between the extent of lung involvement and the height of the blood cholesterol could be detected. For example, in one patient the cholesterol was found to be $111.5 \mathrm{mgm}$. per

CHART III

THe Blood Cholesterol in PNeumonia

CHILDREN Under TWO YeARS

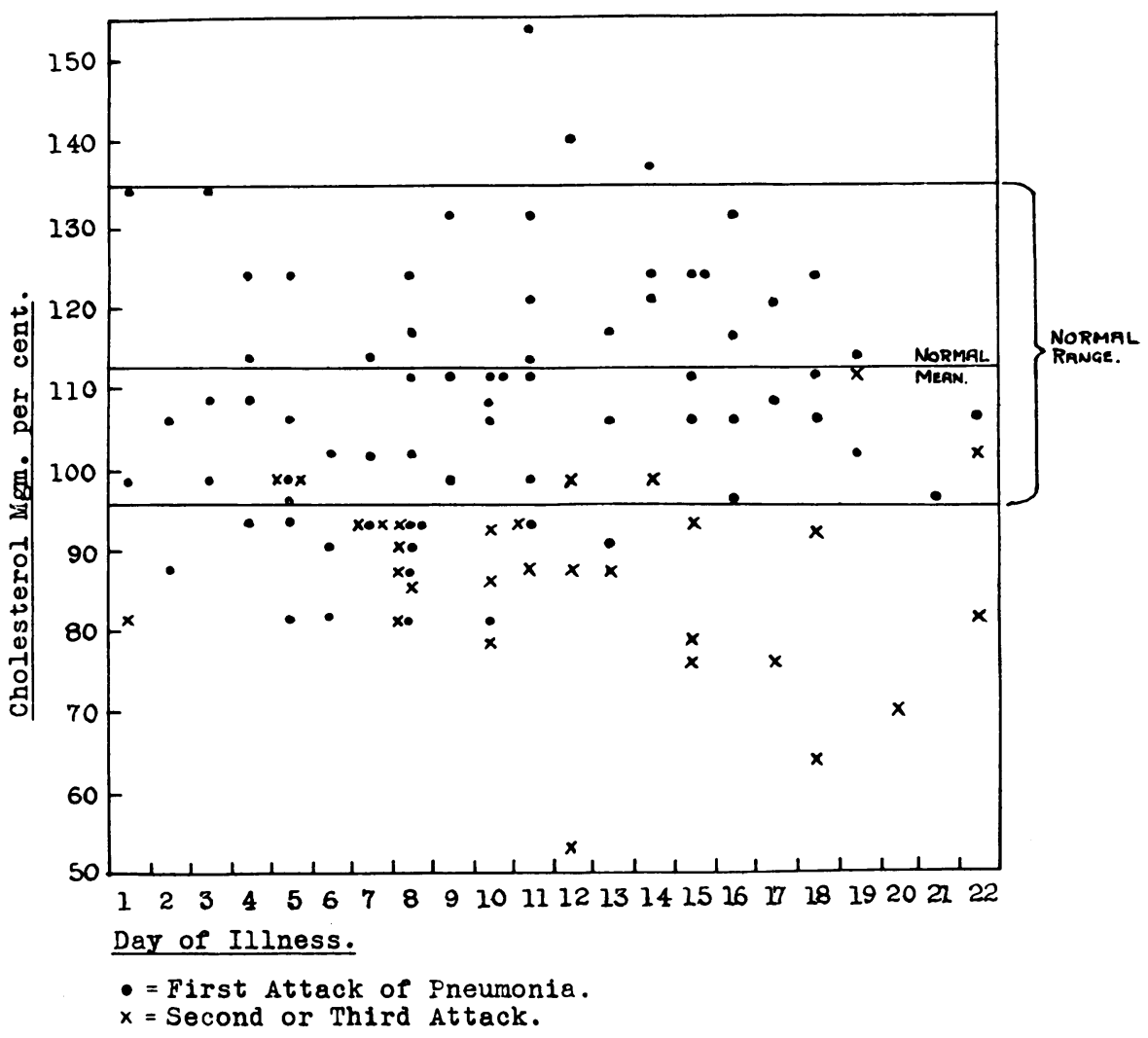

cent. twenty-four hours before death, although at autopsy an extensive suppurative broncho-pneumonia was revealed.

Nine cases of pneumococcal empyema were examined. In six of these the cholesterol value was low, but in one it was high. Four of the children died, and of these two showed hypocholesterolaemia and in two the cholesterol value was within normal limits. In the cases in which there was long-continued sepsis there did not appear to be any tendency for lower values to appear than in those in which resolution was rapid. 
Although these results do not show such striking alteration from the normal as those of some other authorities, there seems little doubt that there is diminution in the blood cholesterol content during the acute stage of pneumonia and in a considerable proportion of cases of empyema. Only in a few cases, however, has it been possible to demonstrate hypercholesterolaemia during the convalescent stage.

The rheumatic infection of childhood. References to juvenile rheumatism in the literature on cholesterol are comparatively scanty, and the few observations published on the subject are somewhat conflicting.

Goldbloom and Gottlieb (1927) made their determinations on whole blood and found hypercholesterolaemia in rheumatic fever. Their work does not appear, however, to have been substantiated by more recent investigators. Ward (1931) and Kaiser and Gray (1934), using whole blood and plasma respectively and employing different methods of estimation, obtained results which differed little from their own normal figures. Offenkrantz and Karshan (1936) found the serum cholesterol within normal limits in acute rheumatism. Lesné et al. (1929) observed normal or slightly elevated values in Sydenham's chorea.

The present series comprised sixty-three cases of juvenile rheumatism. In some patients it has been possible to observe the blood cholesterol values from the initial acute stage for a period of a year or longer. Nine cases were examined during an attack of acute arthritis or within a few days of the subsidence of the acute arthritic manifestations. The blood cholesterol content during this acute stage ranged between $90.1 \mathrm{mgm}$. per cent. and $108.5 \mathrm{mgm}$. per cent. (average 100.3 mgm. per cent.) and with convalescence it rose to an average of $109 \cdot 1 \mathrm{mgm}$. per cent. (table 3). During the subsequent course of convalescence the cholesterol values all tended to rise. There were, however, in a considerable

TABLE 3

THE BLOOD CHOLESTEROL IN ACUTE RHEUMATISM

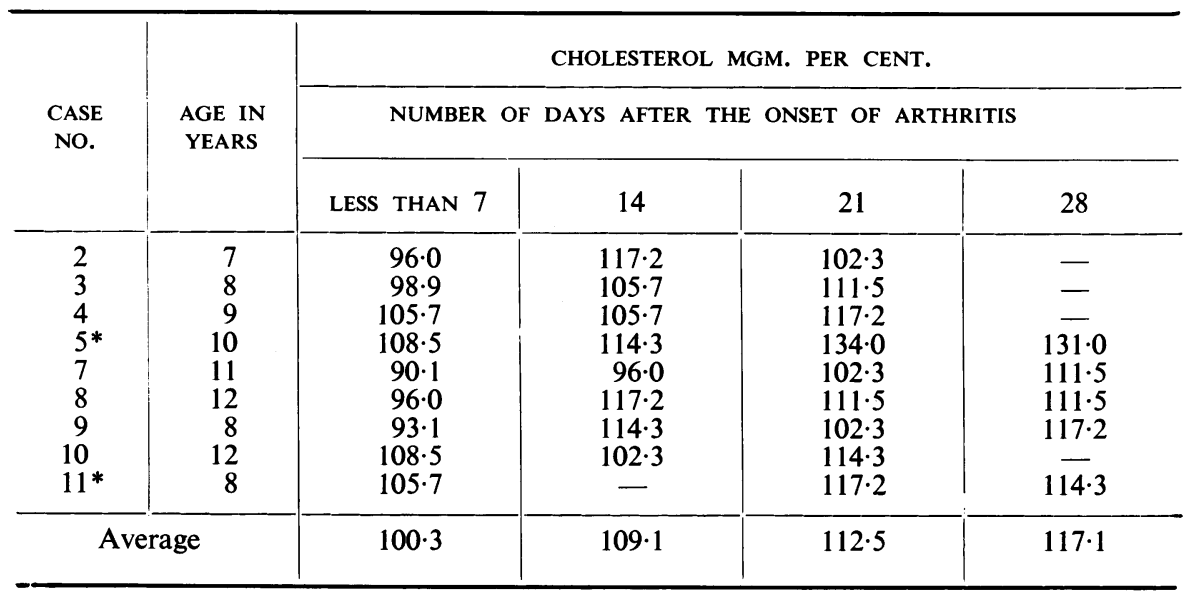

* Second attack of rheumatism. 
number of cases marked oscillations, and it was noted that a fall in the cholesterol value was in many cases associated with tonsillectomy or dental extraction. No consistent changes could be observed with the onset of carditis, though in three of six cases of pericarditis low values were obtained and in four cases of endocarditis with decompensation low values were found in two. In spite of the fact that the development of rheumatic nodules is generally considered to indicate activity of the disease, their presence did not seem to lead to any alteration in cholesterol values.

Serial determinations were made in nineteen children with chorea. None of these showed abnormally low cholesterol values, though in about half of the cases it rose as convalescence progressed.

From these results it seems that in the acute stage of rheumatic arthritis there is frequently a lowered blood cholesterol content which rises as convalescence proceeds and that in pericarditis and cardiac decompensation low values may be found. In the other manifestations of rheumatism such as nodules and chorea no consistent changes could be observed. It seems probable that the initial low blood cholesterol levels found in the acute arthritic stage of the disease are the result of an acute febrile illness and are analogous to the low values which occur in pneumonia. The rheumatic infection, however, in its chronic stages does not appear to influence the blood cholesterol level.

Nephritis. Twelve cases of acute nephritis were studied. Eight of these were observed in the early stages ; they all, save one (case 17), showed low or normal values and within a week of the subsidence of fever the cholesterol rose to above the level observed during the febrile period (table 4). It was also

TABLE 4

THE BLOOD CHOLESTEROL IN ACUTE NEPHRITIS

\begin{tabular}{|c|c|c|c|c|c|}
\hline \multirow{2}{*}{$\begin{array}{l}\text { CASE } \\
\text { NO. }\end{array}$} & \multirow{2}{*}{ TEMPERATURE } & \multicolumn{2}{|c|}{$\begin{array}{l}\text { CHOLESTEROL MGM. PER } \\
\text { CENT. }\end{array}$} & \multirow{2}{*}{$\begin{array}{l}\text { INTERVAL } \\
\text { BETWEEN } \\
(a) \text { AND }(b) \\
\text { IN DAYS }\end{array}$} & \multirow{2}{*}{ OEDEMA } \\
\hline & & $\begin{array}{l}\text { (a) DURING } \\
\text { FEVER }\end{array}$ & $\begin{array}{l}\text { (b) AFTER } \\
\text { FEVER }\end{array}$ & & \\
\hline $\begin{array}{r}1 \\
6 \\
8 \\
11 \\
17 \\
19 \\
22 \\
23\end{array}$ & $\begin{array}{r}99 \cdot 4 \\
99 \cdot 0 \\
99 \cdot 4 \\
100 \cdot 6 \\
99 \cdot 6 \\
102.2 \\
99 \cdot 0 \\
100.0\end{array}$ & $\begin{array}{r}102 \cdot 3 \\
98 \cdot 9 \\
128 \cdot 1 \\
102.5 \\
157 \cdot 4 \\
114.3 \\
96.0 \\
87.3\end{array}$ & $\begin{array}{l}136.9 \\
127 \cdot 6 \\
131 \cdot 0 \\
131 \cdot 0 \\
178 \cdot 1 \\
150 \cdot 6 \\
131 \cdot 0 \\
111 \cdot 5\end{array}$ & $\begin{array}{l}4 \\
7 \\
2 \\
4 \\
3 \\
2 \\
6 \\
5\end{array}$ & $\begin{array}{l}++ \\
- \\
+ \\
+ \\
+ \\
+\end{array}$ \\
\hline
\end{tabular}

observed that an intercurrent infection occurring during the course of the illness produced a diminution in the blood cholesterol. In one child a moderately severe attack of diarrhoea led to a fall of the cholesterol from 164.3 mgm. per 
cent. to $115.5 \mathrm{mgm}$. per cent. within twenty-four hours. In another child an upper respiratory infection with a rise in temperature to $102^{\circ} \mathrm{F}$. was associated with a fall of cholesterol from $131 \mathrm{mgm}$. per cent. to $117 \mathrm{mgm}$. per cent. It is probable that the increase in the cholesterol values found during convalescence in these eight cases was the result of subsidence of the infection which gave rise to the nephritis.

The influence of oedema has also to be reckoned with. It has been claimed on the one hand that in the presence of oedema the blood cholesterol is invariably raised (Maxwell, 1928), whilst on the other hand it is asserted that the occurrence of lipaemia and oedema in nephritis is only a coincidence (Peters and van Slyke, 1931). Oedema occurred in seven cases of the present series. In four of these the cholesterol was low or within normal limits during the oedematous phase and rose with the disappearance of oedema; in three the cholesterol was above normal while oedema was present, but with its subsidence there was a fall to approximately normal limits (table 5). These results lend

TABLE 5

THE BLOOD CHOLESTEROL DURING OEDEMA AND AFTER ITS SUBSIDENCE

\begin{tabular}{|c|c|c|c|c|}
\hline $\begin{array}{l}\text { CASE } \\
\text { NO. }\end{array}$ & DATE & $\begin{array}{l}\text { CHOLESTEROL } \\
\text { MGM. PER CENT. }\end{array}$ & $\begin{array}{l}\text { WEIGHT IN } \\
\text { KGM. }\end{array}$ & OEDEMA \\
\hline 23 & $\begin{array}{l}29 \cdot 11 \\
12 \cdot 12\end{array}$ & $\begin{array}{r}93 \cdot 1 \\
124 \cdot 1\end{array}$ & $\begin{array}{l}24 \cdot 0 \\
20 \cdot 0\end{array}$ & $\begin{array}{l}+ \\
-\end{array}$ \\
\hline 25 & $\begin{array}{r}29 \cdot 7 \\
6 \cdot 8\end{array}$ & $\begin{array}{l}105 \cdot 7 \\
124 \cdot 1\end{array}$ & $\begin{array}{l}25 \cdot 2 \\
20 \cdot 8\end{array}$ & + \\
\hline 19 & $\begin{array}{l}20 \cdot 2 \\
28 \cdot 2\end{array}$ & $\begin{array}{l}114 \cdot 3 \\
120 \cdot 7\end{array}$ & $\begin{array}{l}23 \cdot 0 \\
20 \cdot 6\end{array}$ & 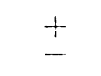 \\
\hline 11 & $\begin{array}{r}27 \cdot 2 \\
7 \cdot 3\end{array}$ & $\begin{array}{l}102.5 \\
136.9\end{array}$ & $\begin{array}{l}14 \cdot 2 \\
12 \cdot 0\end{array}$ & $\stackrel{+}{-}$ \\
\hline 1 & $\begin{array}{r}22 \cdot 11 \\
3 \cdot 12\end{array}$ & $\begin{array}{l}147 \cdot 2 \\
131 \cdot 0\end{array}$ & $\begin{array}{l}29 \cdot 2 \\
24 \cdot 2\end{array}$ & ++ \\
\hline 17 & $\begin{array}{r}3 \cdot 4 \\
22 \cdot 4\end{array}$ & $\begin{array}{l}157 \cdot 4 \\
140 \cdot 0\end{array}$ & $\begin{array}{l}23 \cdot 8 \\
20 \cdot 0\end{array}$ & \pm \\
\hline 9 & $\begin{array}{l}12 \cdot 2 \\
19 \cdot 2\end{array}$ & $\begin{array}{l}157.4 \\
136.9\end{array}$ & $\begin{array}{l}15 \cdot 0 \\
12 \cdot 5\end{array}$ & \pm \\
\hline
\end{tabular}

support to the view that in nephritis the occurrence of hypercholesterolaemia and oedema is no more than a coincidence. Moreover, in oedema arising from certain other causes no increase in the blood cholesterol has been found. In a case of oedema associated with cardiac failure it was $93.1 \mathrm{mgm}$. per cent., in two cases of nutritional oedema $105.7 \mathrm{mgm}$. per cent. and in two infants with oedema of doubtful origin it was $90 \cdot 2 \mathrm{mgm}$. per cent. and $58.6 \mathrm{mgm}$. per cent. respectively. In nephrosis on the other hand it is generally recognized that 
THE BLOOD CHOLESTEROL CONTENT IN CHILDHOOD 263

oedema and hypercholesterolaemia go hand and hand. Three cases of the nephrotic syndrome have been observed for periods of several months and in all more or less parallel changes in the degree of oedema, as indicated by the body weight, and the cholesterol values were found. Estimations were made at frequent intervals and the results are shown in condensed form in table 6.

TABLE 6

THE BLOOD CHOLESTEROL IN NEPHROSIS

\begin{tabular}{c|c|c|c}
\hline CASE NO. & DATE & $\begin{array}{c}\text { CHOLESTEROL } \\
\text { MGM. PER CENT. }\end{array}$ & WEIGHT IN KGM. \\
\hline 54 & 6.1 .36 & $308 \cdot 0$ & $21 \cdot 84$ \\
& 8.2 .36 & $579 \cdot 0$ & $23 \cdot 0$ \\
& 6.3 .36 & $470 \cdot 0$ & $22 \cdot 2$ \\
55 & 22.5 .36 & $299 \cdot 0$ & $18 \cdot 2$ \\
& 2.3 .36 & 214.9 & $27 \cdot 8$ \\
& 1.4 .36 & $398 \cdot 9$ & 30.0 \\
& 8.5 .36 & $444 \cdot 8$ & $30 \cdot 8$ \\
56 & 16.6 .36 & 272.0 & $30 \cdot 6$ \\
& 7.7 .36 & $260 \cdot 0$ & $29 \cdot 6$ \\
& 19.8 .36 & $226 \cdot 0$ & $29 \cdot 2$ \\
& 6.7 .36 & $243 \cdot 0$ & $19 \cdot 32$ \\
& 6.8 .36 & $255 \cdot 0$ & $19 \cdot 28$ \\
& 17.9 .36 & $405 \cdot 5$ & $17 \cdot 72$ \\
\hline
\end{tabular}

Jaundice. Catarrhal jaundice appears to be an exception to the general rule that in febrile conditions the blood cholesterol is reduced. Serial estimations were made in ten children with this condition and in all there was increase in the blood cholesterol (table 7). In seven of the cases there was fever during the early stages and in five of them the blood cholesterol was over $170 \mathrm{mgm}$. per cent. As the jaundice decreased the cholesterol values fell. Three cases of congenital atresia of the bile ducts were examined and all showed high cholesterol values ranging from 140.9 to $204 \mathrm{mgm}$. per cent. (table 8). On the other hand, in uncomplicated haemolytic jaundice no increase in the blood cholesterol was found. In three cases of icterus gravis it ranged between $87.3 \mathrm{mgm}$. per cent. and $90.2 \mathrm{mgm}$. per cent. In a fourth case, however, in which there were signs of obstructive jaundice, probably due to blocking of bile capillaries with pigments, the blood cholesterol was $255.1 \mathrm{mgm}$. per cent. (table 9). In the one case of acholuric jaundice examined the cholesterol value was $75.9 \mathrm{mgm}$. per cent. It would appear, therefore, that in jaundice due to obstruction, even in the presence of fever, there is an increase in the blood cholesterol content, whereas in haemolytic jaundice the values tend to be low. 
ARCHIVES OF DISEASE IN CHILDHOOD

TABLE 7

THE BLOOD CHOLESTEROL IN CATARRHAL JAUNDICE

\begin{tabular}{|c|c|c|c|c|}
\hline CASE & $\begin{array}{l}\text { AGE IN } \\
\text { YEARS }\end{array}$ & DATE & $\begin{array}{l}\text { CHOLESTEROL } \\
\text { MGM. PER CENT. }\end{array}$ & JAUNDICE \\
\hline A. $\mathrm{H}$. & $6 / 12$ & $\begin{array}{r}11.8 .36 \\
1.9 .36\end{array}$ & $\begin{array}{l}251.0 \\
111 \cdot 5\end{array}$ & + \\
\hline M. L. & $19 / 12$ & $\begin{array}{l}13.10 .37 \\
18.10 .37\end{array}$ & $\begin{array}{l}268.0 \\
131.0\end{array}$ & \pm \\
\hline J. C. & 2 & $\begin{array}{r}4.1 .36 \\
14.1 .36\end{array}$ & $\begin{array}{l}255 \cdot 1 \\
111.5\end{array}$ & \pm \\
\hline G. B. & 3 & $\begin{array}{r}7.9 .36 \\
14.9 .36\end{array}$ & $\begin{array}{l}218 \cdot 0 \\
143 \cdot 7\end{array}$ & + \\
\hline B. $\mathbf{S}$. & 5 & $\begin{array}{r}6.10 .36 \\
19.10 .36\end{array}$ & $\begin{array}{l}160 \cdot 8 \\
143 \cdot 7\end{array}$ & + \\
\hline S. McP. & 5 & $\begin{array}{l}18.3 .36 \\
31.3 .36\end{array}$ & $\begin{array}{l}197.0 \\
127.6\end{array}$ & + \\
\hline J. S. & 7 & 10.10 .36 & $185 \cdot 0$ & + \\
\hline M. B. & 7 & $\begin{array}{r}8.11 .37 \\
29.11 .37\end{array}$ & $\begin{array}{l}164 \cdot 3 \\
133.9\end{array}$ & $\begin{array}{l}++ \\
++\end{array}$ \\
\hline W. McG. & 9 & $\begin{array}{r}30.6 .36 \\
4.7 .36\end{array}$ & $\begin{array}{l}150 \cdot 6 \\
108 \cdot 5\end{array}$ & \pm \\
\hline J. D. & 11 & $\begin{array}{r}23.2 .37 \\
6.3 .37\end{array}$ & $\begin{array}{l}143 \cdot 7 \\
105 \cdot 7\end{array}$ & \pm \\
\hline
\end{tabular}

TABLE 8

THE BLOOD CHOLESTEROL IN CONGENITAL ATRESIA OF THE BILE DUCTS

\begin{tabular}{c|c|c|c}
\hline CASE NO. & NAME & AGE IN YEARS & $\begin{array}{c}\text { CHOLESTEROL } \\
\text { MGM. PER CENT. }\end{array}$ \\
\hline 23 & A. L. & $1 / 12$ & $140 \cdot 9$ \\
24 & A. Y. & $6 / 52$ & $208 \cdot 0$ \\
25 & B. & $2 / 52$ & $193 \cdot 1$ \\
\hline
\end{tabular}

TABLE 9

THE BLOOD CHOLESTEROL IN ICTERUS GRAVIS

\begin{tabular}{c|c|c|c|c}
\hline & & & CHOLESTEROL \\
CASE NO. & NAME & AGE IN YEARS & MGM. PER CENT. & RESULT \\
\hline 43 & A. B. & $8 / 365$ & $90 \cdot 2$ & Died \\
44 & R. P. & $2 / 52$ & $90 \cdot 2$ & Died \\
45 & O. D. & $1 / 365$ & $87 \cdot 3$ & Died \\
D. B. & $11 / 365$ & $255 \cdot 1$ & Recovered \\
\hline
\end{tabular}




\section{Summary}

In a group of healthy children the range of blood cholesterol content lay between $96 \mathrm{mgm}$. per cent. and $134 \mathrm{mgm}$. per cent. In pneumonia, empyema, acute rheumatic arthritis and in the early stages of acute nephritis the blood cholesterol content tended to be low and to rise with convalescence. Children suffering from a second or third attack of pneumonia showed low values. In nephrosis and obstructive jaundice high blood cholesterol values prevailed, whereas in oedema due to other causes and in haemolytic jaundice low values were frequently found.

Thanks are due to Professor G. B. Fleming and Professor Noah Morris for suggestions and much valuable advice and criticism. The expenses of this work were partly defrayed by a grant from the Medical Research Council.

\section{REFERENCES.}

Acũna, M., and Winoçur, P. (1931). Arch. Méd. Enf., 34, 409.

Baranski, R. (1926). Ibid., 29, 139.

Baylac, J., and Sendrail, M. (1928). Ibid., 31, 662.

Bloor, W. R. (1916). J. biol. Chem., 24, 447.

- (1933). Ibid., 103, 699.

Blottner, H., and Fitz, R. (1934). J. clin. Invest., 13, 707.

- (1935). Arch. intern. Med., 55, 121.

Callow, R. K., and Parkes, A. S. (1937). Brit. med. J., 1, 456.

Campbell, J. M. H. (1924). Quart. J. Med., 18, 123.

Chaikoff, I. L., McGavack, T. H., and Kaplan, A. (1934). J. clin. Invest., 13, 1.

Chauffard, A., Laroch, H., and Grigaut, A. (1920). Ann. de Méd., 8, 69.

Currie, A. N. (1924). Brit. J. exp. Path., 5, 293.

Denis, W. (1917). J. biol. Chem., 29, 93.

Gainsborough, H. (1935). Proc. roy. Soc. Med., 28, 989.

Gørtz, S. (1937). Acta Paediatr., Stockh., 19, 553.

Goldbloom, A., and Gottlieb, R. (1927). Canad. med. Ass. J., 17, 1333.

Gordon, M. B., and Cohn, D. J. (1928). Amer. J. Dis. Child., 35, 193.

Grigaut, A. (1913). Thèse de Paris.

Kaiser, A. D., and Gray, M. S. (1934). Amer. J. Dis. Child., 47, 9.

Kipp, H. A. (1920). J. biol. Chem., 44, 215.

Leiboff, S. L. (1924). Jbid., 61, 177.

Lesné, E., Zizine, P., and Sylvestre, R. (1929). Rev. franç. Pédiat., 5, 423.

Manicatide, M., Bratesco, A., and Rusesco, R. (1927). C. R. Soc. Biol., Paris, 96, 1240.

Maxwell, J. (1928). Quart. J. Med., 21, 297.

Molitch, M., and Poliakoff, S. (1936). Arch. Pediat., 53, 613.

Offenkrantz, F. M.; and Karshan, M. (1936). Amer. J. Dis. Child., 52, 784.

Peters, J. P., and van Slyke, D.D. (1931). Quantitative Clinical Chemistry, Interpretations, London, 252.

Schube, P. G. (1937). J. Lab. clin. Med., 22, 280.

Simonini, A. (1933). Clin. pediat., Modena, 15, 411.

Sperry, W. M. (1936a). Amer. J. Dis. Child., 51, 84.

- (1936b). J. biol. Chem., 114, 125.

Steiner, A., and Turner, K. B. (1940). J. clin. Invest., 19, 373. 
Stroesser, A. V. (1936). Proc. Soc. exp. Biol., N.Y., 34, 10.

Sylvestre, R. (1929). Thèse de Paris.

Teilum, G. (1935). Acta med. scand., 85, 316.

Vollmer, H. (1927). Z. Kinderheilk., 44, 87.

Ward, K. M. (1931). Arch. Dis. Childh., 6, 329.

Wilson, W. R., and Hanner, J. P. (1934). J. biol. Chem., 106, 323. 